anthropology \& materialism

\section{Anthropology \& Materialism}

A Journal of Social Research

\section{3 | 2016}

\section{Utopia: The Elsewhere and The Otherwise}

\title{
Some Thoughts on the Utopian
}

Quelques réflexions sur l'utopique

Algunas reflexiones sobre lo utópico

\section{Avery Gordon}

\section{(2) OpenEdition}

Journals

Electronic version

URL: http://journals.openedition.org/am/678

DOI: $10.4000 / a m .678$

ISSN: 2364-0480

Publisher:

CETCOPRA, CRASSH - Center for Research in the Arts Social Sciences and Humanities, Fakultät Gestaltung - Universität der Künste Berlin

\section{Electronic reference}

Avery Gordon, «Some Thoughts on the Utopian », Anthropology \& Materialism [Online], 3 | 2016, Online since 25 November 2016, connection on 01 May 2019. URL : http://journals.openedition.org/am/678 ; DOI : $10.4000 / a m .678$

This text was automatically generated on 1 May 2019.

Tous droits réservés 


\section{Some Thoughts on the Utopian}

Quelques réflexions sur l'utopique

Algunas reflexiones sobre lo utópico

Avery Gordon

EDITOR'S NOTE

Originally published in Avery F. Gordon, Keeping Good Time: Reflections on Knowledge, Power and People, Paradigm Publishers, Boulder, London, 2004, pp. 113-132.

\section{The Missing Story}

Utopias have something to do with failure and tell us more about our own limits and weaknesses than they do about perfect societies. Even if one insists

(as I do) that you can't fail unless you try to succeed, the idea is an uncomfortable one and seems to redirect objective inquiries (about social and political difficulties, for example) back into psychological vicious circles which turn on the

desire to lose, or an innate pessimism, or inferiority feelings and paralyzing preconceptions. These unpleasant psychological vices presumably turn out to be my own, although they might cast some doubt on the whole Utopian enterprise itself, insofar as that aims inveterately at passing your conceptual and imaginative time among a host of unrealizable representations. Frederic Jameson, "Utopia and Failure" 
Utopia: failure, psychological vices, unrealizable representations. I start here too since I start with a disappointing confession, which is this: I had hoped to have a really good story to give you. I had hoped to give you an engaging narrative with characters, setting, and a plot that would show you, and not just declare abstractly, something meaningful about utopian consciousness as it is realized and practiced by living people (either now or in the past). I wanted to give you a good story, for one thing, because when you mention utopia, most people, even those sympathetic to hearing the word spoken, immediately want a very practical example or evidence or explanation--a story--that will make them believe you are not just wasting their time with impossible fantasies, faraway lands with seas of lemonade, unrealistic futures, or worse, tyrannical delusions and evil social experiments ${ }^{1}$. The utopian has a bad reputation in many circles, especially radical intellectual ones, and like most people, radical intellectuals sometimes give their prejudices a rest within earshot of a moving story that speaks to them, as if person to person. After all, even radical intellectuals know that the story is not only the point. The story is the mediated meaning of the point, the culture of the point, the source of the point's believability and its persuasive power. The story--even if it's a lie or a clever trickster tale--is what produces the truth. And whatever intelligent scholars think these days about the nature of truth, I've never encountered one who didn't strive to achieve it, whatever her or his version of it was.

So, truth be told, I also wanted to give you a good story because I wanted to have and hold a good story myself. I love a good story. The story has always been my joy and my reason for writing, the reason I'm on the case. The story is what inspires me and needs to be told again. The story is the medium by which I pick up a bit of what's out there in the world, carry the weight of its injuries and inspirations, and then put it down in writing, always trying to remember to carry others along so that the work can reach towards you without your suffering all the trials and tribulations of the weighing and the subtracting of the weight. As Italo Calvino put it in the first of the Six Memos for the Next Millennium he wrote just before he passed away: "My working method has more often than not involved the subtraction of weight. I have tried to remove weight, sometimes from people, sometimes from heavenly bodies, sometimes from cities; above all I have tried to remove weight from the structure of stories and from language." ${ }^{2}$ Removing the weight is important to the working method of writers like me--hanging somewhere between social science and literature--because if you don't remove the weight, it's too easy to feel, as Calvino put it, that the "entire world is turning into stone."3 (Like Medusa's head, he added for effect, and as an aside, well, who wants either to be slain by some entrepreneurial Perseus or to scare people out of their wits with a head full of screaming snakes capable of turning them into stony statues?)

All this is fine and good, but I really don't have a good story to give you. I am utterly certain that there are many really good stories out there--too many in fact. But, the freedom to find one with a passionate attraction to me or to find one to which I am passionately attracted has eluded me so far. Where the freedom of invention resides--a freedom you have to see or feel yourself to believe--there has been hesitation and much second-guessing (which, unfortunately, is far less playful than just guessing). There has been distrust of all possible and probable solutions to the problem of finding the right story for us, and a somewhat inchoate fear of commitment to these possible and probable stories and thus to solving the problem of the missing story. And therefore I've been waiting, waiting for the right conditions, waiting for the next thing or what we call the 
future, waiting for the right story to arrive, as if unbidden, like falling in love before you know any better.

And it's probably no surprise to report that all this waiting has made me depressed, and frankly it's embarrassing to be depressed when you're supposed to be writing about utopian consciousness because aren't utopian thinkers supposed to be fearless and bold and doggedly optimistic and maniacally convinced of nothing else than that they've got a story--the best story in the world, in fact--to tell right this minute! Now my filmmaker friend, Wellington John Bowler, thought that the story of the missing story was itself a pretty funny story. When I told him with a very straight face and much pathos of my predicament, he said, laughing his head off: "That would make a great film, what a wonderful idea for a character! A serious soul trying to write a book about the power of the utopian impulse wanders around depressed, missing all the action, driving herself to distraction and her friends into alternating fits of smug amusement and nurturing concern." "But I don't want to write that story," I whined. "Well, then," my wise young friend concluded, "you better get yourself into another story." And so lesson one: utopian thinking almost always begins with what you're missing and the terrible weight of that loss--the exile of our longing--but you can't get very far unless you lighten up and draw upon whatever other resources you have for being less afraid of what you seek to know and possess.

\title{
II. The Simple Intuition, Nothing Quite like a Hypothesis, More Like a Question of Standpoint
}

\author{
If we are looking for one position from which this \\ work of struggle and renewal has already begun, it \\ is this: that since there are many peoples and \\ cultures, there will be many socialisms. \\ Raymond Williams, "Towards Many Socialisms"
}

The simple intuition that got the whole thing going is that there is something terribly wrong with the picture of helplessness and total social control by remote powers that so characterizes intellectual discourse today. The world is rapidly changing, everyone seems to agree, and for the worse, say a sizable minority. This sizable minority has produced some exceptional critiques of global capitalism's or neoliberalism's human and environmental degradations and its ideological trickery, and it has also reinvigorated an older language of (and hope in) the social change potential of crisis. To be sure, there's plenty of head nodding at the obvious and widespread resistance to the powers that be. But this resistance is almost always described in such qualified and ultimately trivializing terms--merely this or that ultimately futile or contaminated or complicitous or disorganized example of cultural reaction. ${ }^{4}$

A few years ago, the noted writer and essayist John Berger made a plea, "Against the Great Defeat of the World," in response to a letter issued by Zapatista leader Subcommandante Marcos. In this letter Marcos outlined several dimensions of the culture of globalization which comprise, in his words, the "Fourth World War Against Humanity." ${ }^{5}$ In his communiqué, Marcos described in horrific detail a litany of developments whose combined impacts add up to nothing less than an assault on humanity itself. These included the concentration of global wealth and the "extension of hopeless poverties"; the contraction of democratic controls, the intensification of state 
repression and the growth of police states; the stratification of peoples and the breakdown of communities; enforced emigration; and the production of surplus populations, such as the landless, the homeless, and the imprisoned, who are treated as social "waste." He ended his letter by calling for the building of a "new world" to defend the "redundant" and the "next-to-be-eliminated."

In response to Marcos's letter, John Berger replied: "The first step towards building an alternative world has to be a refusal of the world picture implanted in our minds.... In the culture of globalisation, as in ... hell, there is no glimpse of an elsewhere or an otherwise. The given is a prison." To be unable to transcend either the horror or the endemic absurdity of such a world order is what hell means for Berger. Without a glimpse of an elsewhere or an otherwise, we're living in hell.

There is no doubt that this implanted picture of the world is organized, nay industrialized, and powerful. That we are living in a hellish world which appears to outpace our capacities and energy for changing is also true, in part. But it is a particular kind of partial truth: a self-defeating prophecy. For from a different vantage point, the variety of resistance--individual and collective, single and multiply-issued, organized and disorganized, visible and fugitive, loud and quiet, ordinary and extraordinary--is what's remarkable, that is, what ought to solicit more than the mere remark. And among some quarters it does.

People all over the world and in unprecedented numbers are struggling in all kinds of ways--in the streets, on their farms, in their communities and schools--against neoliberalism and structural adjustment and for a sustainable existence. Thousands gathered recently, at the welcoming invitation of the city of Porto Alegre, Brazil, for the third annual World Social Forum. Meeting simultaneously with the World Economic Forum in Davos, Switzerland, the WSF gathers people together to discuss alternatives under the rubric, "Another World Is Possible." South Africans are trying to build a new non-racialist society. Students in Mexico City have been striking over democratic access to higher education for over two years. In the United States, high-school and college students are leading the campaign against sweatshops. Welfare mothers in Kensington, Pennsylvania, have organized an international campaign for economic rights (and a poor people's university) and literally walked their indictment of the U.S. government for economic crimes against humanity to the United Nations. Here and elsewhere, church members are fasting in solidarity with people starving from debt slavery, imagining a non-financialist future, under the rubric of Jubilee 2000. Micro and grassroots radio is flourishing, pirating the monopolized airwaves, democratizing and redistributing the means of communication. Thousands of people, mostly poor black and brown women, are very publicly and very personally rejecting prison as the ideal model of social order. The worldwide peace movement, with its truly remarkable diversity, grows stronger every day. And on and on and on.

These examples only begin to scratch the surface and do not even begin to convey the nature of these struggles or the visions, passions, and longings that motivate them. But motivated they are. Moreover, or more to my point, embedded in this resistance, sometimes explicitly and sometimes implicitly, is both a deep longing for and the articulation of, the existence of a life lived otherwise and elsewhere than in hell. And yet, we seem to have such an underdeveloped and unmoving vocabulary for these longings and these lives, for how people comprehend in a practical embodied way the otherwise and elsewhere. ${ }^{6}$ 
Radical intellectuals, in particular, have highly developed skills in and comfort with critique, with knowing what's wrong with the governing terms of order, with what the problems are. Our first words are often, "The problem is ..." We also use a set of abstract concepts, such as social justice, antiracism, liberation, women of color, freedom, equality, socialism, that function as shorthands for that elsewhere and otherwise, its histories and its cultures. But to my mind, there's a certain emptiness (or otherness) in the ways these vocabularies work, the way they work in the world and also the way they work on us. They antagonistically point to a blind spot--what's in the shadow of the bottom line, so to speak--but they are less successful at evoking or conjuring what stands, living and breathing, in the place blinded from view. ${ }^{7}$ There are good reasons why, for example, we can say a lot more about Jubilee 2000 as an anti-debt initiative and why it's important (also what its limits are) than we can about the non-financialist future it imagines and wants. Very good reasons, but still ... I am looking to write about this utopian place in the shadow of the bottom line, to find a vocabulary for it and how it works, to find and express the fullness of its life-world, to share this finding. On the empirical and historical grounds that it does most certainly exist, that as Toni Cade Bambara's Grandma Dorothy told her, "of course, we know how to fly," and on the hunch that, despite appearances to the contrary, the time is (always) right. ${ }^{8}$

In order to see what's in the shadow of the bottom line, or to see what's standing in the place of a blind spot, one either needs to have or already does have a standpoint for doing so. And I've noticed that a good many of our best critics share with the apologists and triumphalists a standpoint on the world that's very seductive and influential, but which is also a trap, something that holds you in place. This standpoint rests on a belief in the power of global capitalism and its corollary orders to define the very terms not only of what is given, but what could be given as well.

Let me give an example. In 1998, Immanuel Wallerstein published a small book, based on the Sir Douglas Robb lectures he delivered in New Zealand, entitled Utopistics: Or, Historical Choices of the Twenty-first Century. ${ }^{9}$ Although Wallerstein thinks that "the last thing we really need is still more utopian visions ... dreams of heaven that could never exist on earth," he does believe the time is ripe for what he calls Utopistics. "Utopistics is the serious assessment of historical alternatives, the exercise of our judgment as to the substantive rationality of alternative possible historical systems. It is the sober, rational, and realistic evaluation of human social systems, the constraints on what they can be, and the zones open to human creativity. Not the face of the perfect (and inevitable) future, but the face of an alternative, credibly better, and historically possible (but far from certain) future." 10

The reason the time is ripe for utopistics is because we are living in a historical moment Wallerstein calls "Transformational TimeSpace"--"a long and difficult transition from our existing world system to another one or ones."11 Wallerstein predicts this transition will last for around fifty years, but he can't predict whether the "outcome will be better or worse." He's neither "optimistic nor pessimistic," just trying to be "realistic." 12 What's key to Wallerstein's utopistics is that "it is only in moments of systemic bifurcation, of historical transition, that the possibility of establishing overall goals for a world system becomes real." ${ }^{13}$

As the conceptual inventor of what's known as world systems theory, Wallerstein is very clear that a fundamental transformation in a world system is not a normal occurrence. Upheavals, what he calls medium-run changes, swings, revolutions even, are normal to 
the operation of a world system. But, for Wallerstein, there are only two "moments of transition" in a system, two moments in which the system itself is undergoing a fundamental change to its basic function and core identity. These two moments are its beginning and its end. ${ }^{14}$ In these extraordinary periods of transition, something special happens, Wallerstein argues. What is special is that the "free will factor," which is normally severely constrained by the imperatives of the system itself, becomes more prominent, more determinant. As Wallerstein puts it, "I say that when systems are functioning normally, structural determinism outweighs individual and group free will. But in times of crisis and transition, the free will factor ... [is] at its maximum, meaning that individual and collective action can have a greater impact on the future structuring of the world than such action can have in more 'normal' times." 15

For Wallerstein, the free will factor is the extraordinary opportunity for individuals to "understand the nature of our structural crisis," to therefore make "choices for the twenty-first century," and to "struggle" for the realization of these choices, "without any guarantee that we shall win." ${ }^{16}$ The free will factor, then, is the capacity for rational thought and action in circumstances where the outcome of such thought and action is not predictable, but sensitive to intervention. The circumstance or unique condition under which individual and group free will can outweigh structural determinism is whether the capitalist world system itself is in crisis or whether it is functioning normally. You can see then that it's basically up to the system when the free will factor and thus utopistics can have any meaningful impact on the system itself. The precision is important here. Wallerstein cares about systemic change, systemic change is what he's after. He emphatically does not think that the world capitalist system is a fair, democratic, and peaceful system. He doesn't think that everything really always stays the same or even that individual and group action doesn't really change anything. He is, however, establishing the criteria for and aims of utopistics, and he is also arguing that the free will factor is normally subordinated to a superior system with greater scope and authority.

What's the problem? The problem is not entirely with the conceptual language of historical systems. A vocabulary that aims to describe large-scale patterns, often of long duration, is helpful for describing social forces which appear removed from everyday life and which function exactly as if they were remote controls..$^{17}$ Many of us are very reasonably attracted to the idea of a big system out there that determines or creates what seems like an almost invisible bubble or context or underground fault line which contains us or moves us around without our permission. For those who recognize the especially insidious bootstrapping quality of most U.S. ideologies of individualism, The System, like The Man, is a very potent and effective way of identifying real and meaningful limitations on us.

I also don't think the problem here is entirely, as Frederic Jameson put it, "in the philosophically correct use of the concept of totality," by which he means "something that by definition we cannot know" as opposed to "some privileged form of epistemological authority" which "enslaves others." Jameson is right, in my view, to argue that "the thinking of totality itself--the urgent feeling of the presence all around us of some overarching system that we can at least name--has the palpable benefit of forcing us to conceive of at least the possibility of other alternate systems." ${ }^{18}$

The problem with the "privileged" system at the heart of Wallerstein's type of utopistics is that it does not function as merely a philosophical or an empirical mistake. It is a standpoint towards power and resistance to its abuses that has intellectual authority and 
that produces a political culture in which the operations of this world capitalist system are the ultimate measure of critical adequacy. ${ }^{19}$ What's of special concern is the troublesome way in which such a system draws the attention of the analyst constantly towards it. The world capitalist system prevalent in Wallerstein's utopistics yields a preoccupation with and an investment in its fate, regardless of how strict an adherent one is to world systems theory per se. Such an investment is a standpoint tied, for me, directly to the question of fate, by which I mean, tied to asking what is fated for us, to asking who cares about our fate, and to asking to whom our fate can be entrusted. ${ }^{20}$

And this standpoint is the standpoint of the life of the system. The life of the system pulls us in tow and sometimes in thrall. The life of the system is the source of analytical attraction and cathexis. The life of the system is the source of intellectual and political authority. The life of the system sets the fundamental parameters for what is to be known and what can be anticipated. The life of the system is the measure of our freedom, the author of the effectivity of our will. In other words, Wallerstein's free will factor has little instinct for freedom. Its instincts and impulses are always contained by a system which dominates us so thoroughly that it decides when we can "have an impact" on "restructuring the world," which is always relegated to the future. Only from the standpoint of the life of the system could we derive a notion of freedom--the free will factor--so carved out of its very image and so beholden to the system for its effective exercise. Only from the standpoint of the life of the system would we need its sovereign authorization to direct our fate.

Such a standpoint has many costs. One of these costs is a loss of the human freedom and autonomy that utopian thinking cannot and does not, in practice, do without. So, lesson two. There is a delicate balance between understanding and conveying the magnitude and import of longstanding, patterned, and real abusive power systems, and believing in them. This is the balance between fate (or faith perhaps) and fatalism. In other words, beware becoming invested in or in love with that which you claim to despise and which you want to go away.

\section{Obstinacy and Bad Facticity}

$$
\begin{array}{r}
\text { History is calling us to rule again and you lost dead } \\
\text { souls are standing around doing the freakie dickie } \\
\text {... never recognizing the teachers come among you } \\
\text { to prepare you for the transformation, never } \\
\text { recognizing the synthesizers come to forge the } \\
\text { new alliances, or the guides who throw open the } \\
\text { new footpaths, or the messengers to end all } \\
\text { excuses. Dreamer? The dream is real, my friends. } \\
\text { The failure to make it work is the unreality. } \\
\text { Toni Cade Bambara, The Salt Eaters }
\end{array}
$$

"From the beginning," Herbert Marcuse wrote in 1937, "critical theory did more than simply register and systematize facts."

Its impulse came from the force with which it spoke against the facts and confronted bad facticity with its better potentialities. ... [Critical theory] opposes making reality into a criterion in the manner of complacent positivism. ... When truth cannot be realized within the established social order, it always appears to the latter as mere utopia. This transcendence speaks not against, but for its truth. 
The utopian element was long the only progressive element in philosophy, as in the constructions of the best state and the highest pleasure, of perfect happiness and perpetual peace. The obstinacy that comes from adhering to truth against all appearances has given way in contemporary philosophy to whimsy and uninhibited opportunism. Critical theory preserves obstinacy as a genuine quality of philosophical thought. ${ }^{21}$

I admit that everything I have to say could be chalked up to a personality defect: obstinacy. A certain kind of stubborn insistence that taken-for-granted appearances are misleading characteristically defines the work I do. We've all had, I'm sure, experiences where the reaction to a stubborn claim of "bad facticity" is not that we're annoyingly or delightfully stubborn, but rather that we're crazy. Crazy in the colloquial sense of the term and crazy in the psychoanalytic sense, in which all obstinacies are familiar repetitions of the things we've grown fondly accustomed to disliking. Herbert Marcuse's idea of obstinacy as a "genuine quality of philosophical thought" is comforting, obviously, in such a context, since feeling like you're crazy can indeed make you crazy.

Beyond my fascination with people's personalities, I think Marcuse is on to something here when he rejects a certain kind of "reality"--the complacent positivist type--as the "criterion" for telling the truth or knowing what is "given." What Marcuse is objecting to is not descriptivism per se, nor the mistake of confusing appearances and essences. He's not just worried that all positivisms lack explanation--lack an ability to say why something is meaningfully so--and he's not just worried that we won't dig deep enough to capture the systemic or structural foundations of what appears to us as given. Marcuse is objecting to a social realism, or a reality principle, whose facts are shorn of their "better potentialities," by which he means facts and truth regimes in which the "is" is separated from the "could be." What does it mean to confront bad facticity with its better potentialities? Marcuse means something which can be stated simply and which is also a definition of moral calculus. And that is--all critiques, all judgments of what's wrong, or bad, imply a judgment of what's right or good. "You can't know what's wrong with what is if you don't know what could be instead" is its commonsensical formula. Marcuse's concern here is with the consequences of separating the factual from the ethical or the political. When shorn of their better potentialities, the truth cannot be realized at all in those social facts; they are not reliable or good facts that can be supplemented by what they are missing. Rather, for Marcuse, they are analytically deficient or, in his terms, "bad facts." Critical theory rejects all social facts and all knowledge systems--whether nominally Right or Left--which lack calculations of moral sufficiency or deficiency, which stand outside the "could be," because they do not tell the truth. Indeed, the impulse of critical theory, Marcuse states, comes from the force with which it speaks against [these] facts.

Let's presume that Marcuse means something more than the rather important point that the truth is not a positivistic construct, but an ethico-political one. When truth cannot be realized within the established social order, Marcuse continues, it always appears to the latter as mere utopia--such appearance, Marcuse insists, being very much an instance of bad facticity. What does he mean by "mere utopia"? Mere utopia is what we conventionally take utopia to mean: nowhere we can really live, the impossible, the unrealizable future, unrealistic dreams, a luxury for those who can afford to be impractical, "a breeder of illusions and therefore, inevitably, of disillusions."22

The merely utopian is a powerful and established reaction formation quite familiar to us in a variety of social contexts. We hear it in the parent's anxious and disciplining "No" response to a child's extravagant wishes; we hear it in our intimate's protective and 
hesitant response to our most vulnerable dreams; we hear it in the policymaker's calculated and restrained response to innovation and creativity; we hear it in the scientist's genuinely ethical worry over the probability that grand schemes for social change inevitably go very wrong; we hear it in the long-time activist's weary and controlling response to less experienced enthusiasms; we hear it in the critic's tolerant and dismissive evaluation of what's really most important and urgent. The merely utopian is familiar. And we almost always know that we are struggling over the truth when we confront it, and that such a struggle is inextricably bound up with the question, not simply of what is real or realistic, but with the question of what is possible, what could be. In these struggles, the sense that our possibilities are being contained and that the reaction contains a fear of loss--sometimes in ways that are very clear to us, and sometimes in ways that are far more vague and elusive--alerts us to the repressive and managerial function of the merely utopian.

When truth cannot be realized within the established social order, it always appears to the latter as mere utopia. The utopian is not what's impossible, Marcuse is saying; the utopian is what is rejected as bad facticity, not real, not possible. That's why it often appears as the "merely." To adhere to the truths contained in the utopian's bad facticity against all appearances is what Marcuse means by obstinacy, which he strictly distinguishes from whimsy or opportunism. Obstinacy may be irritating, but it is necessary for preventing the merely utopian from being used to disqualify or discredit the elsewhere or otherwise that we know--sometimes as craziness, sometimes as elusive desire, sometimes as our most prized possession--but that we do know is realistic and possible. Or, lesson three: in order to even approach utopian thinking we have to stop associating the utopian with the impossibly idealistic (or with its evil materialist twin, the "never enough") and using it as a weapon against others and ourselves. We'll have to learn to be more comfortable with bad facticity.

\title{
IV. Bad subjects, the Freedom Instinct, and the Deviation
}

\author{
Both in the West and the world beyond, the \\ socialist impulse will survive Marxism's conceits \\ just as earlier it persevered the repressions of the \\ church and secular authorities. The warrant for \\ such an assertion, I have argued, is located in \\ history and the persistence of the human spirit. As \\ the past and our present demonstrate, domination \\ and oppression inspire that spirit in ways we may \\ never fully understand. That a socialist discourse \\ is an irrepressible response to social injustice has \\ been repeatedly confirmed. On that score it has \\ been immaterial whether it was generated by \\ peasants or slaves, workers or intellectuals, or \\ whether it took root in the metropole or the \\ periphery. \\ Cedric J. Robinson, An Anthropology of Marxism
}


And this indeed Marcuse did. When he wrote the 1937 essay, "Philosophy and Critical Theory" from which the "merely utopian" remarks are taken, Marcuse was still quite concerned to establish the objective grounds for the socialism he sought. The visible struggle he's having distinguishing between good facts and bad facts, the struggle to protect the truth, as it were, was part of his fight against German fascism and the need, as he saw it, to expose national socialism as the corruption which suppressed the better truths of a democratic socialism. By 1964, in the swell of post-war affluence and U.S. global power, Marcuse, in One Dimensional Man, certainly gave up on the Western industrial classes as the privileged agents of history and almost despaired that the "needs which demand liberation," as he put it, were being permanently eliminated through organized repressive desublimation. But by 1969, he saw these needs arise again--like renegade ghosts--in what he called "The Great Refusal"--the variety of First and Third world opposition to "the massive exploitative power of corporate capitalism" and its "liberal realizations." ${ }^{23}$ What impressed Marcuse was the radically utopian character of their demands, not so much a "different road to socialism as an emergence of different goals and values, different aspirations in the men and women who resist."

In proclaiming a 'permanent challenge,' ... the Great Refusal, they recognize the mark of social repression, even in the most sublime manifestations of traditional culture, even in the most spectacular manifestations of technical progress. They have again raised a spectre (and this time a spectre which haunts not only the bourgeoisie but all exploitative bureaucracies): the spectre of a revolution which subordinates the development of productive forces and higher standards of living to the requirements of creating solidarity for the human species, for abolishing poverty and misery beyond all national frontiers and spheres of interest, for the attainment of peace. In one word: they have taken the idea of revolution out of the continuum of repression and placed it into its authentic dimension: that of liberation. ${ }^{24}$

It was, then, not until the counterculture and the Black Power, Third World Liberation, women's and students' movements led Marcuse to confront the fact of Marxism's rude indifference to what he called "the idealistic deviation" known as "the subjective factor" (as he said--"the radical utopian character of their demands far surpasses the hypotheses of my own essay"), that he became not just more tolerant but an active supporter of bad facticity. ${ }^{25}$ What else but bad facticity should we call his attempts to establish "a biological foundation for socialism" in the instinct for freedom, in a work dedicated, no less, to those "militants" who dared to take "the life of human beings out of the hands of politicians, managers, and generals"?

In The Essay on Liberation and "The End of Utopia," Marcuse lets loose, forgets for the moment about repressive desublimation and the One-Dimensional Man and goes after this instinct for freedom, goes after it by following the deviant path of subjectivity, by literally following the bad subjects. ${ }^{26}$ And to what end? "To lay bare and liberate the type of man who wants revolution, who must have revolution because otherwise he will fall apart. That is the subjective factor, which," Marcuse cautions, "is more than a subjective factor." 27

Marcuse's writings and thoughts about political consciousness and subjectivity are lengthy and complex..$^{28}$ To simplify matters, in The Essay on Liberation, Marcuse is trying to show that a new society requires new people. As he puts it, "new institutions and relationships of production must express the ascent of needs and satisfactions very different from and ... antagonistic to those prevalent in exploitative societies." ${ }^{29}$ If we do 
not, Marcuse writes, "wish to stop at merely improving the existing state of affairs," we must "accommodate ... the extreme possibilities for freedom ... the scandal of the qualitative difference." ${ }^{30}$

What got Marcuse in trouble with the folks who thought he'd gone too far, following those bad subjects, was not the idea that a free society would be radically different than or antagonistic to the one in which we currently reside. Nor did he get into trouble for arguing that in the making of a free society, "what is at stake are needs themselves." What got Marcuse into trouble was, first, his claim that work on the subjective factor was one of the "chief tasks of materialism today." And second, he essentially defined the subjective factor as the process by which an unfree actor is changed in the here and now so that she or he vitally needs to be free and acts on this need today--not later, not after the revolution, not when the system says its ok, not after the time is right. In other words, not the world system's own rational actor, the free will factor, but the subjective factor, the process by which the willing subject changes itself and its way of existence. This change in the subject constitutes what Marcuse calls "the instinctual basis for freedom." The instinct for freedom Marcuse describes is not a dependent rationality. Its oppositional consciousness does not derive from the logic of the system. Quite the contrary. The instinct for freedom is "the environment of an organism which is no longer capable of adapting to the competitive performances required for well-being under domination, no longer capable of tolerating the aggressiveness, brutality, and ugliness of the established way of life." ${ }^{131}$ And when this organism follows the instinct for freedom, or what Fred Moten calls the "freedom drive," 32 adapting to it, making of it a home, Marcuse continues, "rebellion" has "taken root in the very nature, the 'biology' of the individual" ${ }^{33}$ and our way of existence is changing. ${ }^{34}$

What I find compelling in Marcuse's idea of the subjective factor is his unabashed enthusiasm for liberation and his passionate insistence that the instinctual basis for freedom--the ways in which the need for freedom without exploitation and misery, expressed in both our aspirations and our behaviors--can and must become our "second nature." ${ }^{35}$ To become our second nature, we require what Marcuse called sensory "organs for the alternative." ${ }^{16}$ This is quite an interesting and "unnatural" biology, as cultural and political resistance is its antithetical core; not a very disciplined science, and certainly not, I think, socio-biology with its emphasis on adaptation. Indeed, Marcuse uses the word biology to "designate the process ... [by] which inclinations, behavior patterns, and aspirations become vital needs which, if not satisfied" will cause us to fall apart. ${ }^{37}$ Human nature is always changing, Marcuse notes. But changing what feels natural to us and what we privilege and recognize as authority; changing the very skin that envelopes our first reactions, or the behaviors we repeat automatically, or the calculations and sacrifices that define our very sense of survival--these changes are slow and painful. These changes are met with powerful social and psychic resistance. These changes make us feel as if we are falling apart. Switching the electrifying poles that carry the currents of value so that we experience falling apart entirely differently--so that our entire sensitivity apparatus recoils at what it previously loved--this is what it means to work on the subjective factor. And this work is individual and collective, a form of solidarity. "Socialist solidarity," Marcuse writes, "is autonomy. Self-determination begins at home ... that is with every I, and the We whom the I chooses. And this end must ... appear in the means to attain it ... in the strategy of those who ... work for the new [society]. ... The existential quality ... of the new Form of life ... must show forth, anticipated and demonstrated, in the fight for their 
realization. Exploitation in all its forms must ... disappear ... from this fight ... from the ... relationships among the fighters ... and from their individual relationships." 38

Work on the subjective factor, the deviation, is not the work of normal science, social or physical. Indeed, Marcuse is aware of the strain he's putting on the meaning of the word "biology" to use it as he does: the word is always followed by a question mark. There's no mistaking the anti-positivism in Marcuse's organs for the alternative, a hallmark of the older tradition of utopian socialism which Marx and Engels so famously sought to supercede. ${ }^{39}$ And Marcuse certainly reverses Marx and Engels's logic, which required that the path to socialism proceed from utopia to science. It will, it must, work the other way around, Marcuse suggests. Marcuse might have used the word culture instead of biology, but it was already overtaken by his old colleagues and made an unrelenting source of corruption and complicity. It would be left to Marcuse's African contemporary, Amilcar Cabral, to name the freedom drive culture. ${ }^{40}$ The word biology suffices then to capture what Marcuse is aiming for: how to cultivate and liberate the instinct or drive for freedom.

Cultivating an instinctual basis for freedom is about identifying the longings $s^{41}$ that already exist--however muted or marginal or extreme--and turning these longings into vital needs, into things that we cannot and will no longer live without. Cultivating an instinctual basis for freedom is about acquiring the sensual knowledge that our survival depends on sacrificing only what is blocking the satisfaction of those vital needs, without which we would otherwise fall apart. Cultivating an instinctual basis for freedom is about being obstinate that survival is a condition which does not exist when it is obtained at the expense of the suffering of others ${ }^{42}$ or of oneself. Cultivating an instinctual basis for freedom is about cultivating an individual and collective indifference to all the promises of happiness, worth, and freedom that deliver their opposites or morally degraded versions of themselves. Cultivating an instinctual basis for freedom is about creating a solidarity in which "consciousness of ... the heritage of oppression" is accompanied by "understanding" and "tenderness towards each other." Cultivating an instinctual basis for freedom is about the "ingression of the future into the present." 43

Cultivating an instinctual basis for freedom, then, is the delicate and difficult process of making the qualitative difference possible and realistic, a part of who we are as a people and thus accepted as reality instead of rejected as the merely utopian. "We must accommodate ... the extreme possibilities for freedom ... the scandal of the qualitative difference," Marcuse says. In other words, we have to make room for the active presence of this extreme instinct for freedom, which is a scandal because it achieves a qualitative difference that is everywhere denied as existent or even possible.

And so lesson four: a practical utopian consciousness is scandalous, which no doubt accounts for the tremendous repression and shame that it attracts. This practical consciousness is a standpoint, a way of seeing and being from the point of view of the scandal of the qualitative difference. From this standpoint, the cultivation of the instinct for freedom is a necessary condition for effective social change, for changing our way of existence. From this standpoint, the systems that dominate us are only, as Cedric J. Robinson puts it, "one condition of our being." ${ }^{44}$ From this standpoint, utopian thinking doesn't wait for authorization from a superior system or a higher power to direct our fate. From this standpoint, we authorize ourselves--a monumental act of freedom in the authoritarian world in which we live. From this standpoint, then, the utopian is not the 
future as some absolute break from the past and the present, out there. It is in us, a way we conceive and live in the here and now.

\title{
V. A Different Reality Principle
}

\author{
Social theory is concerned with the historical \\ alternatives which haunt the established society as \\ subversive tendencies and forces. The values \\ attached to these alternatives ... become facts \\ when they are translated into reality by ... \\ practice. \\ Herbert Marcuse, One-Dimensional Man
}

To summarize, Wallerstein's Utopistics relies on systemic contradiction to generate and warrant a rationalistic will to change. Marcuse and many theorists subsequent (and prior to) him have rightly found this model of social change and its historical materialism deficient, for some of the reasons I've already given. Marcuse offers a richer and more insightful conception of the utopian because he insists that changing "the system" requires deeply changing people. The subjective factor-the instinct for freedom-is neither residual nor epiphenomenal; it's part of the historical material. But, Marcuse's approach has been criticized for not explaining very well how it is exactly that an instinct for freedom can organize a new way of existence if our current existence is thoroughly contaminated by the "aggressiveness, brutality, and ugliness of the established way of life." Critics have found Marcuse's claims unrealistic because they seem to rest on an unevidenced and theoretically unwarranted libidinal individualism.

Both Wallerstein's and Marcuse's models of utopian thinking are important ones. But their limitations have fueled a suspicion towards the utopian, even among those sympathetic to it, which must, in my view, be overcome. Here is Frederic Jameson describing this sympathetic suspicion: "If you know already what your longed-forexercise in a not-yet-existent freedom looks like, then the suspicion arises that if may not really express freedom after all but only repetition; while the fear of projection, of sullying an open future with our own deformed and repressed social habits in the present, is a perpetual threat to the indulgence of fantasies of the future collectivity." 45 Jameson captures quite elegantly the contradictory feelings that generate reservations about the autonomy of the utopian project. I say autonomy because utopian thinking is not dismissed out of hand, but its relative autonomy is. By autonomy, I mean independence, capacity for leadership, self-determination. Even under sympathetic conditions--your longed-for-exercise-a ubiquitous complicity takes intellectual and emotional precedence. At the core of these reservations and anxieties is the presumption, as Jameson goes on to state, that "freedom [...] cannot be defined in advance, let alone exemplified" ${ }^{46}$ Freedom is what we fight for, but not what we possess now. Freedom is what we will acquire at some future time when the battles are won and when the systemic supports for new needs, desires, people, and institutions are established. What Jameson is saying is that the utopian is always paralyzed-spooked, some would say-by what represses and oppresses us. Inevitably trapped by that which presumably motivates it in the first place-the need for a freedom that's missing or that there isn't enough ofthe utopian drags the suspicion along with it that it is never really itself. 
This is a very sophisticated and persuasive position, especially since it is usually accompanied by the sine qua non of critical adequacy: a description of the systematic and all-encompassing nature of the power or powers that dominate, including the variety of resistance and opposition. In this position, ambivalence towards freedom supposedly protects its integrity. One consequence is that the utopian, as a rule, is always and should be deferred into the future: later, maybe, we'll know the difference between freedom and repetition. A second consequence is that there's an analytic, affective, and practical split between the diagnosis and space, so to speak, of what's wrong--the injury, the violence, the dehumanization, the exploitation, the bondage-and the space of what's good-what's humane, sustainable, emancipated, liberated, free.

My somewhat obstinate view is that there is can be no utopian thinking under this presumptive segregation. The utopian is not only or merely a "fantasy of" and for "the future collectivity. It is not simply fantasmatic or otherworldly in the conventional temporal sense. The utopian is a way of conceiving and living in the here and now, which is inevitably entangled with all kinds of deformations and ugly social habits. That it is our self-appointed duty to protect the future from our "deformed and repressed social habits" is more accurately viewed, I think, as the conceit which legitimates the deferral and disqualification of the utopian. ${ }^{47}$ For one thing, and to put it crudely, if we could protect future generations thus, we would not be in this contradictory predicament at all. Utopian thinking, then, requires a different approach than ambivalence to the problem of repetition and projection, so that legitimate concerns about the sufficiency of our ideas and behaviors do not block utopian thinking by further repressing it, but rather, to use a much-maligned word, liberate it so that it may be in charge of itself.

Haunting, in the way I understand it at least, helps with this very understandable problem of wanting to separate what harms you-what you need utopianism for-from what frees you. I'll try to explain how.

Haunting is one prevalent way in which modern systems of power make themselves known and their impacts felt in everyday life. Haunting is not the same as being exploited, traumatized, or oppressed, although it usually involves these experiences or is produced by them. Haunting is quintessentially an animated state in which a repressed or unresolved social violence is making itself known, sometimes very directly, sometimes more obliquely. Haunting describes those singular and yet repetitive instances when home becomes unfamiliar, when your bearings on the world lose direction, when the over-and-done-with comes alive, when what's been in your blind-field comes into view. Haunting raises specters, and it jams time--the way we separate the past, present, and future. Ghosts appear when the trouble they represent and symptomize is no longer being contained or repressed or blocked from view. Ghosts arise or haunting occurs when repression or blockage is not working. It is important to emphasize that the ghost, as I understand it, is not the invisible, or the missing, or some ineffable excess. The whole essence, if you can use that word, of a ghost is that it has a real presence and moreover is demanding its due, your attention. The ghost or haunting is a way we are notified that what's been contained or repressed or blocked is very much alive and present, messing with the variety of ways we have to keep the troublesome from rattling around the house or appearing at inopportune moments, like at work.

Haunting is a frightening experience. It always registers the harm inflicted or the loss sustained by a social violence done in the past or in the present. Haunting can and does produce traumaticic paralysis or destructive repetitive compulsions. It can cause us to 
project our "deformed and repressed social habits" all over the place, including into our politics and into the future. Some of us are very familiar, too familiar, with this. But haunting very often produces a something-to-be-done, and this something-to-be-done brings us into the domain of the utopian. Or it did me. In Ghostly Matters, the utopian appeared as a kind of understudy to the main character: as longing, as the object of the state's repression, as part of who we are, and as what motivated ultimately the whole analysis of haunting. At the end of book, I wrote,"Haunting always harbors the violence, the witchcraft and denial that made it, and the exile of our longing, the utopian." ${ }^{48}$

I called the utopian the exile of our longing for non-sacrificial freedoms and exuberant unforeseen pleasures, treating it as a political or social unconscious. ${ }^{49}$ I do think the utopian is very much bound up with what has been exiled, and I'm very concerned with what's been left behind when these longings are banished to the social margins. I also think that our deepest utopian aspirations are often so bound up with loss that they cannot help but leave us feeling melancholy. But, as I try to make the utopian the first and not the last word, this passage makes me think about what it means to have described the utopian as something that haunts the social order.

In treating the utopian as something that haunts, I drew on a statement by Marcuse about the purpose of social theory which has guided my work as a social theorist and which influenced Ghostly Matters. It is, ironically, a statement Marcuse made at the beginning of One-Dimensional Man, the book in which his despair over the possibility of radical social change was most pronounced. He wrote, "Social theory is concerned with the historical alternatives which haunt the established society as subversive tendencies and forces. The values attached to these alternatives ... become facts when they are translated into reality by ... practice." ${ }^{50}$

I've always treated this passage as an epistemological instruction and a reality principle. From the vantage point of this reality principle, the "historical alternatives" are not missing or locked away in some elusive or fantastic futurity. The alternatives and the values attached to them are already here in our given present-time, haunting what's established, making the present waver, making it not quite what we thought it was. From the vantage point of this reality principle, the utopian haunts. And, if the utopian haunts, it has to be present and visible and knowable because there is no haunting without ghosts, and ghosts are the felt sense and presence of the things, people, and knowledge which were supposed to be gone or not-there. If the utopian haunts, it is disruptive and unsettling because haunting is frightening. The haunting presence of subversive forces and alternative values striving to become social facts is very frightening because it is a testament to the reality of living better and otherwise than we're expected to do. That indeed can make the present waver, make it not quite what we thought it was.

Seeing that the utopian is a haunting presence or is part and parcel of haunting itself helps solve the segregation problem by making the utopian more present, by making it part of the trouble that haunting registers and stirs up. But, when I called the utopian the exile of our longing for non-sacrificial freedoms and exuberant unforeseen pleasures, I treated those desires as if they had no home, as if they were always destined to be extradited to some elusive place where exiled longings live. I do think the utopian is very much bound up with what has been exiled, and I'm very concerned with what's been left behind when the longings for a humane existence are banished to the social margins. I also think that our deepest utopian aspirations are often so bound up with loss that they cannot help but leave us feeling melancholy. 
And so lesson five: The utopian is its own mode or form and it exists as more than a haunt. It exists in all those examples of the things we are and do that exceed or are just not expressions of what's dominant and dominating us. It exists when there is no painful split between the dream world and the real world; when revolutionary time doesn't stop the world, but is rather a daily part of it; when needs and desires and investments are already being re-engineered; when a second nature or a sixth sensory organ has already grown and taken root. It exists when the utopian is not the future as some absolute break from the past and the present, but a way of living in the here and now. The utopian is not only the exile of our longing for non-sacrificial freedoms. I was wrong about that. It is something more. It is the articulation of social movement in the general sense of the term: the ongoing building of an alternative civilization, with its own reason, its own home, and its own system of value.

\title{
VI. But How do we Know for Sure? Who's to Say That... Where are the Guarantees?
}

\author{
For all these utopians ... socialism is ... a mere \\ accident. ... Each one's special kind of absolute \\ truth, reason and justice is ... conditioned by his \\ subjective understanding, his conditions of \\ existence, the measure of his knowledge and ... \\ intellectual training. ... Hence from this nothing \\ could come but a kind of eclectic ... mish-mash, \\ allowing ... the most manifold shades of opinion ... \\ critical statements, economic theories, [and] \\ pictures of society. ... To make a science of \\ socialism, it had first to be placed upon a real \\ basis. \\ Frederick Engels, Socialism: Utopian and Scientific ${ }^{51}$ \\ In Alexis de Tocqueville's Recollections, we're told \\ of a day in June 1848 . We're in a lovely apartment \\ on the left bank, seventh arrondissement, at \\ dinner-time. The Tocqueville family is reunited. \\ Nevertheless, in the calm of the evening, the \\ cannonade fired by the bourgeoisie against the \\ rebellion of rioting workers resounds suddenly-- \\ distant noises from the right bank. The diners \\ shiver, their faces darken. But a smile escapes a \\ young waitress who serves their table and has just \\ arrived from the Faubourg Saint Antoine. She's \\ immediately fired. Isn't the true specter of \\ communism perhaps there in that smile? The one \\ that frightened the Tsar, the pope ... and the Lord \\ of Tocqueville? Isn't a glimmer of joy there, \\ making for the specter of liberation? ${ }^{52}$
}

The scandal of the qualitative difference is well-captured by the unsettling power of the waitress's smile. (It is not the smile of a ghost, but rather the smile of the servant who has 
suddenly and unexpectedly appeared as a secret agent, exposing nothing more but nothing less than the existence of another intelligent world they do not and cannot own or dismiss.) The scandal of the qualitative difference is what Marx and Engels tried to avoid by making socialism into a science rather than a "utopian" "mish-mash." The scandal of the qualitative difference is also what Charles Fourier, whom Engels thought exemplary of the mish-mash problem, tried to avoid, both by publicly censoring his wildest ideas about passion and sex, and by making a science of passionate attraction and the Harmony it would produce. ${ }^{53}$ For both these men (and for Marx too, and I apologize for holding Engels responsible for only popularizing a collaborative idea), ${ }^{54}$ social science was the key to "accommodating the extreme possibilities of freedom"--even if in Fourier's case the social science was a cosmological, classificatory one designed to de-stigmatize and institutionalize sexual and other emotional "manias" and the joys of pear-picking, and thus quite different from Marx and Engels's science of historical materialism. There's much more to say about Fourier who was an astounding critic of Western civilization's "savants" and a remarkable thinker in so many ways. Nonetheless, in both cases the recourse to social science was at the heart of their grave mistakes, the glue that held their respective projects together and the glue that kept them stuck.

But there's perhaps a more empathic, if still cautionary, point to be made here. Even though Engels's science/utopia distinction became, in the hands of those infighting, sectarian Second Internationalists, a weapon to wield against internal dissenters and heretics and to pass down as Marxist political culture, ${ }^{55}$ and even though Fourier's calculus of the Destinies, based on his science of "absolute doubt" and "absolute deviation," became the major reason he was dismissed as a lunatic, the whole promise of social science, for them, was that they believed it would guarantee the possibility of a less alienating and more fulfilling collective life.

The irony is that Engels actually lived more of a such a life and, although it's purely speculation on my part, I think he was able to do so because of his attachment to poetry (which was the form his earliest anti-merchant radicalism took), to social activism, to ethnography, to Mary Burns, the Irish working-class woman with whom he lived for many years, and to taking care of others and redistributing his wealth. But this life was not enough for Engels; he required other guarantees for what makes change desirable, possible, and real. This guarantee, which he found in scientific laws, shrank the vision he collaborated with Marx to produce. ${ }^{56}$ Fourier's vision, by contrast, was much greater-wild and imaginative and funny and quite brilliant, about the need to institutionalize not ideal individuals but good conditions for the shared and equitable expression of our complicated and unruly passions and needs. But he lived the life of the isolated visionary--lonely, bitter, and demanding of others, especially of those who most loved and respected him. Nothing was ever enough for him and his actual life was as far from his vision of Harmony as it could be. Harmony was literally the place he exiled his longings. And, in that disapora, he too needed to establish the guarantees missing in his own life and in the real world which so frightened him.

But there are no guarantees. No guarantees that the time is right (that is, no historical laws); no guarantees that just a little more misery and suffering will bring the whole mess down; no guarantees that the people we expect to lead us will (no special privileged historical agents); no guarantees that God or Newton or the Genome Project is on our side; no guarantees that we can protect future generations or ourselves from "our deformed and repressed social habits," if we just wait long enough or plan it all out ahead 
of time; no guarantees that on the other side of the big change, some new utterlyunfathomable-but-worth-waiting-for happiness will be ours. ${ }^{57}$ Neither normal nor maniacal social science can give us a secure guarantee or even a really secure calculation of the probabilities. The search for the secure guarantee responds to a basic need that should not be trivialized, but the secure guarantee often requires a complicated contract. One of the reasons utopian socialists are almost always dismissed as simplistic is because, whatever their strengths and weaknesses, they "carry on regardless" of this contract, with perhaps more simple beliefs. ${ }^{58}$ Or, with something which good magic can make seem so simple: the suspension of disbelief.

And so we return, at the end, to the problem of fate (or perhaps faith). There are no guarantees of coming milleniums or historically inevitable socialisms or abstract principles, only our complicated selves together and a reliable reality principle in which the history and presence of the instinct for freedom, however fugitive or extreme, is the evidence of the utopia's possibility because we've already begun to realize it. Begun to realize it in those scandalous moments when the present wavers, when it is not quite what we thought it was. There are no social scientific guarantees, only the active and intelligent use of what Marcuse, in an effort to invalidate the opposition of reason and imagination, called "our faculties of freedom." ${ }^{59}$ No guarantees, but for me just an obstinate wish to shift my critical gaze towards that utopian place or structure of feeling where the instinct for freedom resides. Why? In the end, or maybe it's just the beginning, "the point of such a shift is not to deny in an act of willful disregard the calamities of abusive authority, the alienations of exploited labor, the violence of dictatorial ideas, or the dehumanization of our capacities and habits." ${ }^{60}$ The point is to expose the illusion of supremacy and unassailability dominating institutions and groups routinely generate to mask their fragility and their contingency. The point is simply to encourage those of us who see ourselves as politically engaged radical intellectuals or social change activists to be a little less frightened of and more enthusiastic about our most scandalous utopian desires and actions. Knowledge for social movement ought to move us as well as educate us, and for this it requires a particular kind of courage and a few magic tricks.

\section{NOTES}

1. For the seas of lemonade, see Jonathan Beecher and Richard Bienvenu, eds., The Utopian Vision of Charles Fourier: Selected Texts on Work, Love, and Passionate Attraction (Boston: Beacon Press, 1971). See James Scott, Seeing Like a State (New Haven: Yale University Press, 1998), on modernist social experiments gone wrong.

2. Italo Calvino, Six Memos for the Next Millennium (New York: Vintage, 1993), p. 3.

3. Ibid., p. 4.

4. See Russell Jacoby, The End of Utopia: Politics and Culture in an Age of Apathy (New York: Basic Books, 1999). Jacoby, along with Todd Gitlin, is one of the worst exemplars of self-appointed left managerialism, but he speaks for others. That's why the others continue to speak to him. Many of us know from experience and from hundreds of years of history what it means to be trivialized and dismissed as a "merely" this or that. See below on the "merely Utopian." 
5. See John Berger, "Against the Great Defeat of the World," Race \& Class 40, no. 2/3 (October 1998 -March 1999), pp. 1-4. Subcommandante Marcos's letter, "The Fourth World War Has Begun," is available in a variety of translations and therefore versions. The most accessible is the one in Le Monde Diplomatique, English Edition, August-September 1997.

6. For living in temporary autonomous zones, see Hakim Bey, Millennium (Brooklyn: Autonomedia, 1996) and TAZ, Temporary Autonomous Zones, Ontological Anarchy, Poetic Terrorism (Brooklyn: Autonomedia, 1991). Thanks to Mick Taussig for introducing Bey's work to me.

7. See J.K. Gibson-Graham, The End of Capitalism (as we knew it): A Feminist Critique of Political Economy (Cambridge: Blackwell, 1996), p. 259, for socialism as capitalism's opposite--"a great emptiness on the other side of the membrane, a social space where the fullness of capitalism is negated." The End of Capitalism (as we knew it) is an extremely bold and spirited exposé of "capitalocentrism." Gibson-Graham's attempt to dismantle the density of capitalism as a conceptual given deserves serious attention. The End of Capitalism is stronger, in my view, in conveying the standpoint of "capitalocentrism" and its colonizing tendencies, than it is in filling in that "empty social space" where capitalism is "negated." The self/other model used and the commitment to a notion of economic totality may be what leads to the unfortunate situation in which the "haunting" noncapitalist activities identified have no names of their own.

8. Toni Cade Bambara, "The Education of a Storyteller" in Deep Sightings and Rescue Missions: Fiction, Essays, and Conversations, ed. Toni Morrison (New York: Pantheon, 1996), p. 255.

9. Immanuel Wallerstein, Utopistics: Or, Historical Choices of the Twenty-first Century (New York: The New Press, 1998), p. 1.

10. Ibid., pp. 1-2.

11. Ibid., pp. 3, 65 .

12.

Ibid. p.

90.

13. Ibid., pp. 2-3.

14. Ibid., p. 12. I'm leaving aside the question of whether it is possible to make these distinctions other than retrospectively, whether it is possible to know contemporaneously whether a system is acting normally or whether it's beginning or ending.

15. Ibid., pp. $64,36$.

16. Ibid., pp. 88-9.

17. See Fernand Braudel, The Wheels of Commerce (New York: Harper \& Row, 1982) on the distinction between "material life" ("the stratum of the non-economy") and capitalism. Braudel's attempts to define capitalism by distinguishing between where it exists and where it does not is fascinating and thought-provoking. Giovanni Arrighi provides an excellent summery of Braudel's argument and a longer discussion in The Long Twentieth Century (London: Verso, 1994), p. 10ff.

18. Frederic Jameson, Seeds of Time (New York: Columbia University Press), pp. 69-70.

19. The phrase is from Cedric J. Robinson, An Anthropology of Marxism (Aldershot, England: Ashgate, 2001).

20. On fate, fatalism and standpoints, see my "Preface" to Cedric J. Robinson, An Anthropology of Marxism, xviii-xix, chapter 17 below.

21. Herbert Marcuse, "Philosophy and Critical Theory" (1937) in Negations: Essays in Critical Theory, trans. Jeremy J. Shapiro (London: Free Association Books, 1988), p. 143. Angela Davis brought this passage to my attention. I thank her for sharing it with me and also for our ongoing dialogue about Herbert Marcuse, critical theory, and vocabularies of resistance.

22. Wallerstein, Utopistics, p. 1.

23. Herbert Marcuse, An Essay on Liberation (1969) (Middlesex, England: Penguin Books, 1973), p.15.

24. Ibid., p. 11.

25. Marcuse grappled with the objective/subjective, good fact/bad fact business all his life. It nagged at him, for good reason, but he kept pushing it to the margins just as he continued to 
grapple with the Marxist distinction between freedom and necessity, but increasingly only in the footnotes.

26. Herbert Marcuse, "The End of Utopia," in Five Lectures: Psychoanalysis, Politics, and Utopia, trans. Jeremy J. Shapiro and Shierry M. Weber (Boston: Beacon Press, 1970), p. 74.

27. Ibid.

28. I am not offering a comprehensive interpretation of Marcuse's thought, which would require greater attention to Marcuse's reliance on the notion of false needs, to his influential analysis of "repressive desublimation," and to his admitted difficulty in resolving the problem of the relationship between necessity and freedom. I have selectively taken from Marcuse what is useful for my own purposes. That said, it is also the case that I believe I have captured the spirit of what Marcuse was aiming for. Moreover, I think it is worthwhile to celebrate his uninhibited enthusiasm for utopian subjectivity, derived almost entirely from the inspiration he took from a variety of social movements "incompatible with traditional forms of political struggle," (Essay on Liberation, p. 91) because he was so criticized for it. More than just criticized, he was subjected to the patronizing treatment of having his thoughts on the matter disassociated from his "real contributions" and dismissed as indulgent romanticism best ignored. See Stanley Aronowitz's essay on the centennial of Marcuse's birth in Social Text, a surprising example of this tendency given Aronowitz's more consistent positions. Douglas Kellner remains Marcuse's most comprehensive and respectful commentator and scholar. See his Herbert Marcuse and the Crisis of Marxism (Berkeley: University of California Press, 1984). See also http://www.gseis.ucla.edu/ faculty/kellner/Illumina\%20Folder/marc.htm, Kellner's web page on Marcuse which includes, among other items, a stream for Herbert's Hippopotamus, Paul Alexander Juutilainen's film about Marcuse.

29. Marcuse, Essay on Liberation, p. 14.

30. Marcuse, "End of Utopia," p. 69.

31. Marcuse, Essay on Liberation, p. 14.

32. See Fred Moten, In the Break (Minneapolis: University of Minnesota Press, 2003).

33. Marcuse, Essay on Liberation, p. 14.

34. Marcuse, "End of Utopia," p. 65.

35. Marcuse, Essay on Liberation, p. 20. Although approached from the point of view of "anthropological" claims about the "human species," Cosimo Quarta in "Homo Utopicus: On the Need for Utopia," Utopian Studies, Spring 1996, pp. 153-167, makes a related argument about the utopian as second nature.

36. Marcuse, Essay on Liberation, p. 26.

37. Ibid., p. 20.

38. Ibid., p. 90.

39. See Saskia Poldervaart, "Theories about Sex and Sexuality in Utopian Socialism," Journal of Homosexuality 29, no. 2-3 (June-July 1995), pp. 41-67 and "Utopianism and Feminism: Some Conclusions" in Feminist Utopias in a Postmodern Era, ed. Alkeline van Lenning, Marrie Bekker, and Ine Vanwesenbeeck (Tilburg, The Netherlands: Tilburg University Press, 1997), pp. 117-94.

40. See Amilcar Cabral, Unity and Struggle: Speeches and Writings, trans. Michael Wolfers (New York: Monthly Review Press, 1979) and Amilcar Cabral, Return to the Source: Selected Speeches by Amilcar Cabral, ed. African Information Service (New York: African Information Service, 1973).

41. Marcuse, Essay on Liberation, p. 27.

42. Ibid., p. 23.

43. Ibid., p. 90, 91.

44. Cedric J. Robinson, "Manichaeism and Multiculturalism" in Avery Gordon and Christopher Newfield, eds., Mapping Multiculturalism (Minneapolis: University of Minnesota Press, 1997), p.122.

45. Jameson, Seeds of Time, pp. 56-7.

46. Ibid., p. 56. 
47. See Walter Benjamin, "Theses on the Philosophy of History" in Illuminations, ed. Hannah Arendt, trans. Harry Zohn (New York: Schocken Books, 1969). Benjamin makes a similar point when he distinguishes between those who are "firmly convinced that even the dead will not be safe from the enemy if he wins" and those who are only "nourished by the image of ... liberated grandchildren," p. 255, 260.

48. Avery F. Gordon, Ghostly Matters: Haunting and the Sociological Imagination (Minneapolis: University of Minnesota Press, 1997/2008), p. 207.

49. See Frederic Jameson, The Political Unconscious: Narrative as a Socially Symbolic Act (Cornell University Press, 1981) and Erich Fromm, "The Social Unconscious" in Beyond the Chains of Illusion (New York: Pocket Books, 1962).

50. Herbert Marcuse, One-Dimensional Man (Boston: Beacon Press, 1964), pp. xi-xii.

51. Frederick Engels, Socialism: Utopian and Scientific, trans. Edward Aveling (New York: International Publishers, 1975), pp. 43-4.

52. Antonio Negri, “The Specter's Smile” in Ghostly Demarcations: A Symposium on Jacques Derrida's "Specters of Marx", ed. Michael Sprinker (London: Verso Books, 1999), p.15.

53. See Jonathan Beecher and Richard Bienvenu, eds., The Utopian Vision of Charles Fourier (University of Missouri Press, 1983).

54. I hate to hold Engels responsible because Marx had a lot to do with this and because poor Engels was always having to be responsible for Marx. Engels had to do Marx's empirical research work for him, had to take care of him financially, had to endlessly defer to and stroke the other's ego, had to suffer Marx's patronizing disdain of his live-in relationship with Mary Burns, showing the most despicable cruelty and indifference towards Engels's feelings when Burns passed away. Engels was responsible for popularizing Marx, and also for basically writing everything that had to meet a publication deadline. Nonetheless, it was Engels who concocted the science/utopia distinction in the 1880 text. Engels's critique of St. Simon, Owen and Fourier is, quite frankly, not very persuasive. It is widely known that he actually admired these three, and mostly what he has to say about them in Socialism: Scientific and Utopian is laudatory. The reasons for his ultimate dismissal of them are there in the text--they misunderstood the laws of historical materialism, they were pre-historic, they did not adequately valorize class conflict and the inevitable destiny of the proletariat, they wanted to liberate all humanity at once. But the reasons don't add up and Engels knows this, which is why he just throws up his arms--metaphorically--and cries, out with the "mish-mash"! See Gareth Steadman Jones, "Engels and the History of Marxism," and Eric Hobsbawn, "Marx, Engels, and Pre-Marxian Socialism" in Eric Hobsbawm, ed., The History of Marxism (Bloomington: Indiana University Press, 1982).

55. On the Second International, see Vincent Geoghegan, Utopianism and Marxism (London: Methuen, 1987). See also Rosa Luxemburg's letters to Leo Jogiches in Rosa Luxemburg, Comrade and Lover: Rosa Luxemburg's Letters to Leo Jogiches, ed. and trans. Elzbieta Ettinger (Cambridge, MA: MIT Press, 1979), a tragic account of her terrible struggle with the science/utopia divide as the politics/life/love divide.

56. We measure this shrinkage more easily today: the disregard for non-industrial labor by peasants, slaves, indentured servants, women; the limitations of an exclusive focus on class and class struggle, rooted in a two-class model, the economism that prevented a more complex engagement with gender, sexuality, culture, race, language, history, and everyday life; the absolute refusal to entertain the idea that their European world was not the only one or the only model.

57. In "Against the Great Defeat of the World," John Berger writes on page 1, "Most prophecies, when specific, are bound to be bad, for, throughout history, there are always new terrors--even if a few disappear, yet there are no new happinesses--happiness is always the old one. It is the modes of struggle for this happiness which change." 
58. See Raymond Williams, "Hesitations before Socialism," in Resources of Hope (London: Verso, 1989): "Every few years some people announce that socialism, finally, is dead. They then read the will and discover, unsurprisingly, that they are its sole lawful heirs. Socialists meanwhile carry on. All too often indeed we carry on regardless. We are so used to the parting shots of a long line of careerists and compromisers that we often fail to notice quite different voices which are addressing a genuine crisis: always, in practice, a crisis of change. It's as if socialism were some unchanging entity, a perfected and timeless system handed down by its pioneers, and now, look, it has gone wrong and must be abandoned. ... But socialism, in spite of some of its propagandists, has never really been of this kind. It has been a movement of many different kinds of people, in very different historical situations. It has repeatedly overlapped with other movements: of democratic advance, of social welfare, of national liberation. Its most distinctive vision has been of a society in which people are free to identify and relate, in their places, beyond the rule of capital and its agents. Yet both analysis and vision have occurred under definite historical pressures and within clear social and historical limits" (288). "We have always drawn our real strength" (not from "the coming millenniums" or "a historically inevitable socialisms" or abstract ideas) but from our "actual relationships and experiences in our own lives" (283).

59. Marcuse, Essay on Liberation, p. 38.

60. Avery Gordon, "Preface," in Cedric J. Robinson, An Anthropology of Marxism, pp. xvi-xvii and chapter 17 below.

\section{AUTHOR}

\section{AVERY GORDON}

Avery Gordon is a Professor of Sociology at the University of California, Santa Barbara and Visiting Faculty Fellow at the Centre for Research Architecture, Department of Visual Cultures, Goldsmiths College, University of London. 